\title{
SZÉTHÚZÓ FALVAK, EGYSÉGES VÁROSOK? ${ }^{1}$
}

\author{
(Divergent Villages, Parallel Cities?)
}

\author{
GERGELY JÚLIA
}

\begin{abstract}
Kulcsszavak:
városfejlödés agglomeráció szuburbanizáció szegregáció

Az utóbbi években, évtizedekben egyre jelentösebb társadalmi átrendezödések figyelhetök meg Budapest agglomerációs övezetében. A társadalomszerkezet változásának elsödleges oka a szuburbanizáció jelensége, egyik fontos következménye pedig a települések közötti térbeli-társadalmi szegregáció erösödése. Eltéró azonban az elkülönülés mértéke és alakulása a falvak és a városok településcsoportjainak esetében, míg a falvak között eröteljesebb, addig a városok között enyhébb a széthúzás foka.
\end{abstract}

\section{Bevezetés}

Budapest vonzáskörzetének települései, azok lakosság-összetétele és ezzel az agglomerációs gyürü társadalomszerkezete az utóbbi években, évtizedekben sokat változott. E változások feltérképezése, nyomon követése mindenképpen érdekes és kihívásokkal teli városszociológiai feladat. Az övezet társadalmi átrendeződésének felmérésére jelen tanulmányban egy kevéssé elterjedt módszert, a szegregációs indexek módszerét alkalmazzuk. Ezek segítségével igyekszünk bemutatni a területen a társadalmi változások egyes következményeit, az élesedő térbeli-társadalmi elkülönülést, illetve a falvak és városok helyzetének eltérő alakulását.

Az utóbbi években, évtizedekben markáns átalakulás zajlik Budapest agglomerációs övezetében, mely átalakulás egyre jelentósebb mértékü társadalmi átrendezödéssel jár együtt. A társadalomszerkezet gyors változásának elsődleges oka a szuburbanizáció jelensége, azaz a nagyszámú betelepülő lakos megjelenése az övezetben (és ezzel párhuzamosan a ki- és átköltözések elszaporodása). Míg a beköltözök korábban inkább az ország távolabbi pontjairól, a közelmúltban és ma elsősorban a fóvárosból érkeznek. A népességmozgással végbemenő folyamatok az egyes településeken belül, valamint az agglomerációs övezet területének összességében is számos (kedvező és kedvezőtlen) következménnyel járnak. A hirtelen lakosságnövekedés egyik fontos következménye a települések közötti (település szintú) és a településen belüli (egyéni szintú) térbeli társadalmi elkülönülés, a szegregáció megjelenése vagy erôsödése. Az elkülönülés alapja - mindkét szinten - az újonnan betelepülők lakóhely választásának célirányos volta, illetve az újonnan érkezők beilleszkedési lehetőségeinek gyakori hiánya, bizonyos esetekben az elkülönülés tudatos igénye.

A Budapesti agglomeráció esetében ráadásul nem csak a hagyományos értelemben vett szuburbanizációról, tehát a tehetősebb, magasabb státuszú népesség 
fővárosból való kiköltözéséröl beszélhetünk, hanem egy jóval alacsonyabb státuszú népesség (budapesti életüket, lakásukat fenntartani nem képes lakosság) lakóhely változtatási kényszeréről is. A lakossági kiáramlás tekintetében meghatározó, hogy az eltérö társadalmi rétegekböl érkezők eltérö területeket választanak az agglomerációs gyürün belül, illetve az egyes kiválasztott települések esetében is. Agglomerációs és települési szinten is megfigyelhetöek és jól körülhatárolhatóak a magasabb státuszúak által preferált területek (akik ezáltal még jobb helyzetbe kerülnek), és ettöl elkülönülten találhatóak az alacsony státuszúak kényszerböl „választott” új lakóhelyei (akik helyzete ennek köszönhetöen tovább romlik). Míg a teljes agglomerációban az egyre magasabb és az egyre alacsonyabb státuszú településcsoportok között, addig a településeken belül az öslakosok és az újonnan betelepülők között tapasztalható a térbeli szétválás.

Jelen tanulmányban az agglomerációs övezet települései között alakuló, változó szegregáció kérdésével fogunk foglalkozni. Ennek vizsgálatára lehetöséget nyújthatnak a népszámlálások településsoros adatai - a következő, 2010-es népszámlálás remélhetöleg a legújabb folyamatok bemutatását is lehetővé fogja majd tenni.

\section{A Budapesti agglomeráció - egy kis történelem}

Budapest és az agglomeráció növekedése nem egységes folyamat, a legnagyobb változások több ciklusban mentek végbe (Beluszky 1999; Schuchmann 2001). Schuchmann Péter (2001) osztályozásában az első szakasz kezdete 1873, a városegyesítés (Pest, Buda és Óbuda egyesítésének) időpontja, melynek során elsősorban a föváros belső területei indultak meg a fejlődés útján. A második szakasz a huszadik század első fele, amely a környezö települések lakosságszámának emelkedését, új települések létrejöttét, az első agglomerációs övezet kialakulását hozta. Ezt követte a harmadik szakasz, amely Nagy-Budapest 1950-es létrehozásával (az akkori 23 peremtelepülés fövároshoz való csatolásával) indult, és amely elsősorban ismét a (már megnövekedett) fôvároson belül hozott jelentősebb változásokat. A negyedik szakaszban, a bevezetett adminisztrációs korlátozások mellett², elöbb a föváros peremterületein, majd az 1980-as évektől, azaz az ötödik szakasz kezdetétől Budapest vonzáskörzetében kezdett drasztikusan emelkedni a lakosságszám. Ez utóbbi szakasz az első lépés, az igazi szuburbanizáció azonban inkább csak a kilencvenes években kezdődött, melynek során részben a budai hegyvidék telkeinek felaprózása, beépítése, részben a főváros melletti települések lakótelepes, később lakóparkos beépítése valósult meg.

A Budapesti agglomeráció első hivatalos lehatárolása 1971-ben történt. Ekkor az 1005/1971. (II.26.) számú kormányhatározat Budapesttel együtt 45 települést sorolt a fóváros agglomerációjához. Különböző szakmai vizsgálatok már az 1980-as évtized elején jelezték, hogy az agglomerálódási folyamatok túlterjedtek ezen a területen, az újabb jogszabály ${ }^{3}$ azonban csak jóval később, 1997-ben született meg, amely az agglomeráció területéhez a fövárossal együtt összesen 79 települést sorolt. Ma a budapesti agglomeráció hivatalosan 81 települést foglal magában, aminek nem a terü- 
leti lehatárolás változása, hanem két-két település szétválása az oka ${ }^{4}$. Habár a területtel foglalkozó szakemberek jelentős része egyetért abban, hogy ma a főváros vonzáskörzete nagyobb a hivatalosan rögzítettnél $1^{5}$, jelen tanulmányban agglomeráció alatt a KSH által meghatározott területet értjük, amely hivatalos adatgyüjtési és tervezési egység, valamint kiemelt fejlesztési régió (KSH 1998). A hivatalos beosztás az agglomerációs övezet településeit hat szektorba sorolja, ezek az Északnyugati, a Nyugati, a Déli, a Délkeleti, a Keleti és az Északi szektorok ${ }^{6}$.

\section{Hogyan mérhető a szegregáció?}

A szegregáció fogalma, vizsgálata, módszerei az Egyesült Államokból származnak. A szegregáció mérésének igénye először az 1940-es, 1950-es években fogalmazódott meg, az amerikai nagyvárosokban élő afro-amerikai lakosság egyre szembetúnőbb területi koncentrációjának - a gettók és slumok kialakulásának - megértése, elemezhetősége végett (Beveridge 2002). Eleinte szegregáció alatt kizárólag a fekete és fehér lakosság térbeli elkülönülését értették, más társadalmi csoportokkal a terület kutatói nem foglalkoztak. Később, a szegregáció fogalmának elterjedése után, számos városkutató a lakóhelyi elkülönülés mérésének lehetőségeivel kezdett foglalkozni, különböző térbeli egyenlőtlenségi mérőeszközöket, indexeket kezdett kidolgozni.

Magyarországon a térbeli egyenlőtlenséget mérő indexek, illetve a szegregáció mérésének különböző módszerei, a szegregációs mérőeszközök, néhány kivételtől eltekintve nem terjedtek el széles körben. Ebben az elemzésben a települések közötti szegregáció alapvetö vizsgálati módszere mégis az úgynevezett szegregációs indexekkel történő összehasonlítás lesz. Ez a módszer alkalmas a vizsgált terület adott dimenzió mentén fennálló heterogenitásának vagy homogenitásának számszerüsítésére és az időbeli összehasonlításra.

A szakirodalom több szegregációs mutatót is számon tart, amelyek közül elemzésünkben a leggyakrabban előforduló, legtöbb kutató által elfogadott két indexet használjuk ${ }^{7}$, ezek: a Disszimilaritás index és a Gini index (Massey-Denton 1988) ${ }^{8}$. A Disszimilaritás index (D) ${ }^{9}$ az egyenletességtől való eltérést méri. Értéke azt mutatja meg, hogy a teljes kisebbség mekkora részének (százalékának) kellene elköltöznie ahhoz, hogy eloszlása a teljes területen egyenletes legyen. Az index értéke 0 és 1 között mozog, ahol: $\mathrm{D}=0$, ha a terület maximálisan integrált, azaz a területek között a két csoport megoszlása teljesen azonos, és $\mathrm{D}=1$, ha a terület maximálisan szegregált, azaz a két megoszlás egymást kizáró - ahol az egyik csoport előfordul, ott a másik egyáltalán nem képviselteti magát. A mutatót, amennyiben nem az alapsokaság két kiemelt csoportjára vonatkozik, hanem egy kiválasztott csoport és az összes többi csoport összehasonlitásán alapul, szokás szegregációs indexnek is nevezni. A másik mérőszám az olasz származású Corrado Gini által bevezetett, a Disszimilaritás indexhez hasonló, azt kiterjesztő Gini index $(G)^{10}$. A Disszimilaritás indexhez hasonlóan ez a mutató is 0 és 1 között mozog, ahol az 1 -es érték a maximális szegregációt jelöli ${ }^{11}$. 
Szegregációt mindig egy adott, pontosan körülhatárolt területen lehet mérni, a teljes terület kisebb egységei között. Méréséhez szükség van tehát egy nagyobb, lehatárolt területre, valamint több, ezt lefedö kisebb körzetre, amelyek között az elkülönülés mértéke vizsgálandó. Szükség van továbbá két csoportra, ezek között kérdéses a szegregáció mértéke. A két csoport lehet egy kisebbség (diplomások) és a hozzá tartozó többség (nem diplomások), vagy két szélsőséges - ugyanazon dimenzió mentén meghatározott - kisebbség (diplomások és iskolázatlanok). Elemzésünkben a szegregációs indexeket az eredetileg meghatározott módtól kicsit eltérően, az aktuális kutatáshoz igazítottan használjuk. A szakirodalom a lakóhelyi szegregáció alatt egy adott településen annak kisebb körzetei (például számlálókörzetei vagy kerületei) között fennálló térbeli társadalmi egyenlötlenséget érti. Kutatásunkban a teljes vizsgált terület a Budapest körüli agglomerációs gyürü, azaz nem egy település, hanem egy összefüggő településtest. A kisebb területi egységek, körzetek pedig az agglomeráció egyes települései. Azt gondoljuk, a fent vázolt módszer lehetővé teszi azt, hogy az agglomerációs övezet majdhogynem összenött települései között mérjük segítségével a térbeli társadalmi elkülönülést.

\section{Települések közötti szegregáció a Budapesti agglomerációban}

A szakirodalom, valamint az elérhető mikro és makro adatok alapján minden jel arra utal, hogy a fỏvárosból az agglomerációs gyürü településeire való átköltözés különböző mintázatokat mutat. A KSH adataiból egyértelmüen kjderül, hogy az egyes szuburbán települések nem egyforma mértékben fogadják az újonnan beköltözni vágyókat. Vannak települések, amelyek - vagy saját tudatos stratégiájukból adódóan, vagy a fỏvárosból költözni vágyók vagy kényszerülök igényeiböl és lehetőségeiböl következöen - ,felkapottabbak”, így lakosságszámuk gyorsabban nö, és vannak olyanok, amelyek kevésbé népszerüek, lakosságszámuk így lassabban emelkedik, esetleg stagnál, vagy akár csökken. A vonatkozó szakirodalomból az is egyértelmüen kiderül, hogy - úgy tünik - a magasabb státuszú beköltözők az övezet települései közül más területeket választanak, mint az alacsonyabb társadalmi rétegekböl érkezök (Szirmai 1998; Csanádi-Csizmady 2002). Ha ez utóbbi megállapítás igaz, akkor annak mindenképpen következményekkel kell járnia. Ilyen következmény lehet a települések, régiók erősödö társadalmi széthúzása, illetve az övezet egyes területeinek fel-, más részeinek leértékelődése. Azok a települések ugyanis, amelyek inkább a magasabb társadalmi pozícióval rendelkező lakosságot vonzzák, egyre jobb, míg azok a települések, amelyek a leszakadóbb rétegekből érkezőket fogadják be, egyre rosszabb státuszúakká válhatnak. Ezek következtében erősödhet a területen a térbeli társadalmi elkülönülés, a szegregáció.

A települések közötti szegregáció vizsgálatára kiváló lehetőséget teremtenek az 1980-as, az 1990-es és a 2001-es népszámlálás településsoros adatai, amelyek lehetővé teszik a területen fennálló (pl. a lakosok iskolázottsági összetétele vagy a lakáshelyzet alapján vizsgált) társadalmi státuszbeli különbségek mérését, illetve a 
változások nyomon követését. Ezeket az adatokat a fent leírt módszerrel elemezve valóban bemutathatóak a területen egyre markánsabban elkülönülő régiók, megfigyelhető a nyugati-északnyugati, a déli, valamint a keleti-északkeleti szektorok széthúzása, a körkörös, vagy réteges elhelyezkedés, illetve a városok és a falvak helyzetének eltérő alakulása. Megkülönböztethetök az agglomeráció dinamikusan fejlődő szuburbán és az egyre jobban leszakadó, egyre elmaradottabb területei.

\section{Mennyiségi mutató: vándorlás}

Az agglomerációban a társadalmi változások alapja - úgy tünik - elsősorban a kiés beköltözők magas száma. Mivel közvetlen mobilitási adatok nem állnak rendelkezésre, a budapesti népességfogyásból, az agglomerációs népességnövekedésböl, valamint az agglomerációban tapasztalható jelentős lakásállomány emelkedésből vonhatunk le következtetéseket.

\section{TÁBLÁZAT}

A lakónépesség számának alakulása az agglomerációs övezetben (Inhabitant Population's Number in the Agglomeration)

\begin{tabular}{|c|c|c|c|c|c|c|c|}
\hline & \multicolumn{7}{|c|}{ A lakónépesség } \\
\hline & \multicolumn{3}{|c|}{ száma (fó) } & \multicolumn{2}{|c|}{ változása $(f o ̈)$} & \multicolumn{2}{|c|}{ változása (\%) } \\
\hline & 1980 & 1990 & 2001 & $\begin{array}{c}1980- \\
1990\end{array}$ & $\begin{array}{c}1990- \\
2001\end{array}$ & $\begin{array}{c}1980- \\
1990\end{array}$ & $\begin{array}{l}1990- \\
2001\end{array}$ \\
\hline $\begin{array}{l}\text { Pest megye } \\
\text { (Budapest } \\
\text { nélkül) }\end{array}$ & 973830 & 949842 & 1083877 & -23988 & 134035 & 97,5 & 114,1 \\
\hline Budapest & 2059226 & 2016681 & 1777921 & -42545 & -238760 & 97,9 & 88,2 \\
\hline $\begin{array}{l}\text { Agglomeráció } \\
\text { (Budapest } \\
\text { nélkül) }\end{array}$ & 566675 & 566961 & 675394 & 286 & 108433 & 100,1 & 119,1 \\
\hline $\begin{array}{l}\text { Agglomeráció } \\
\text { városai }\end{array}$ & 299657 & 306616 & 356392 & 6959 & 49776 & 102,3 & 116,2 \\
\hline $\begin{array}{l}\text { Agglomeráció } \\
\text { falvai }\end{array}$ & 267018 & 260345 & 319002 & -6673 & 58657 & 97,5 & 122,5 \\
\hline
\end{tabular}

Forrás: KSH 2001. évi népszámlálás.

A vándorlási egyenleget tekintve a vizsgált három évtized alapvetóen eltér egymástól. Az adatokból egyértelmúen látszik (1. táblázat), hogy az utolsó tíz évben mutathatók ki a szuburbanizáció igazi jelei. A föváros lakónépessége 1990 és 2001 között 10,1\%-kal csökkent, ezzel szemben Pest megye lakossága, különösen az agglomerációs övezetbe tartozó területeké folyamatosan nött, az elöbbi 14,1\%-kal, az utóbbi 19,1\%-kal. Az agglomerációban a falvak lakónépességének növekedése $(22,5 \%)$ meghaladta a városokét $(16,2 \%)$. Feltehető, hogy az agglomerációs népességnövekedés forrása jelentős mértékben a föváros népességcsökkenése volt. Az ezt megelöző tíz évben, 1980 és 1989 között a teljes agglomeráció lakónépességének száma stagnált, mely stagnálás azonban nem a vándorlások teljes hiányából, hanem 
annak alacsony és egymást elnyomó tendenciáiból adódott. A városokban valamelyest (közel 7000 fövel, 2,3\%-kal) emelkedett, a községekben közben ugyanennyivel csökkent az összes lakók száma. Még korábban, 1970 és 1979 között a területek többségén pozitiv vagy legalábbis stagnáló lakosságszám-változás volt tapasztalható, ami nem a Budapestről, sokkal inkább az ország egyéb területeiről érkező betelepülőknek volt köszönhetö ${ }^{12}$.

\section{Minőségi mutató: iskolai végzettség}

A következỏ lépésben a települések közötti szegregációt két dimenzióban fogjuk vizsgálni, ezek az iskolai végzettség alakulása és a lakáshelyzet kérdése. Ezen minőségi mutatók esetében már alkalmazhatók a szegregációs indexek is, hiszen itt különböző csoportok vethetök össze. Az iskolázottságot és a lakáshelyzetet is a népszámlálási adatok segítségével elemezzük, megvizsgáljuk a szegregáció alakulását a diplomások és az iskolázatlanok (tehát az iskolai végzettségükben szélsőséges csoportok), az utóbbi időszakban és a korábban épült lakással, illetve az összkomfortos és a komfort nélküli lakással rendelkezök között.

$\mathrm{Az}$ iskolai végzettséget vizsgálva a területi elkülönülés mértékét - a három időpontban - a következő csoportok között elemezzük: iskolázatlanok - iskolázottak; diplomások - diploma nélküliek; iskolázatlanok - diplomások. A diplomával való rendelkezést a magas, az iskolázatlanságot az alacsony társadalmi státusz jelének tekintjük. Fontos megjegyezni, hogy a vizsgált időszakban jelentősen csökkent az iskolázatlanok, és növekedett a magasan kvalifikáltak aránya a terület valamennyi településén. 1980 és 2001 között az iskolázatlanok száma 126 257-röl 41 632-re csökkent, míg a diplomával rendelkezök száma 19 880-ról 70 570-re nőtt. Ezzel mindkét csoport területbeli aránya is megváltozott.

\section{TÁBLÁZAT}

Az iskolai végzettség szerinti szegregáció az agglomerációs övezetben (Educational Segregation in the Agglomeration)

\begin{tabular}{lccc}
\hline & 1980 & 1990 & 2001 \\
\hline & \multicolumn{3}{c}{ iskolázatlan-iskolázott } \\
Disszimilaritás index & 0,110 & 0,113 & 0,117 \\
Gini index & 0,155 & 0,156 & 0,163 \\
\hline & \multicolumn{4}{c}{ diplomás - diploma nélküli } \\
Disszimilaritás index & 0,220 & 0,219 & 0,210 \\
Gini index & 0,298 & 0,298 & 0,294 \\
\hline & \multicolumn{4}{c}{ iskolázatlan-diplomás } \\
Disszimilaritás index & 0,279 & 0,283 & 0,267 \\
Gini index & 0,373 & 0,378 & 0,369 \\
\hline
\end{tabular}

Forrás: Saját számítás. 


\section{TÁBLÁZAT}

Az iskolai végzettség szerinti szegregáció az agglomeráció városaiban és falvaiban (Educational Segregation in the Agglomeration's Cities and Villages)

\begin{tabular}{|c|c|c|c|c|c|c|}
\hline & \multicolumn{3}{|c|}{ Városok } & \multicolumn{3}{|c|}{ Falvak } \\
\hline & 1980 & 1990 & 2001 & 1980 & 1990 & 2001 \\
\hline & \multicolumn{3}{|c|}{ iskolázatlan-iskolázott } & \multicolumn{3}{|c|}{ iskolázatlan - iskolázott } \\
\hline $\begin{array}{l}\text { Disszimilaritás } \\
\text { index }\end{array}$ & 0,109 & 0,099 & 0,107 & 0,085 & 0,084 & 0,098 \\
\hline \multirow[t]{2}{*}{ Gini index } & 0,142 & 0,132 & 0,146 & 0,117 & 0,117 & 0,141 \\
\hline & \multicolumn{3}{|c|}{$\begin{array}{c}\text { diplomás - diploma } \\
\text { nélküli }\end{array}$} & \multicolumn{3}{|c|}{$\begin{array}{c}\text { diplomás - diploma } \\
\text { nélküli }\end{array}$} \\
\hline $\begin{array}{l}\text { Disszimilaritás } \\
\text { index }\end{array}$ & 0,191 & 0,178 & 0,176 & 0,160 & 0,185 & 0,219 \\
\hline \multirow[t]{2}{*}{ Gini index } & 0,260 & 0,235 & 0,245 & 0,226 & 0,253 & 0,298 \\
\hline & \multicolumn{3}{|c|}{ iskolázatlan - diplomás } & \multicolumn{3}{|c|}{ iskolázatlan-diplomás } \\
\hline $\begin{array}{l}\text { Disszimilaritás } \\
\text { index }\end{array}$ & 0,247 & 0,230 & 0,222 & 0,200 & 0,229 & 0,262 \\
\hline Gini index & 0,328 & 0,297 & 0,305 & 0,277 & 0,306 & 0,356 \\
\hline
\end{tabular}

Forrás: Saját számítás.

A kapott eredményeket megfigyelve (2. és 3. táblázat), első ránézésre az időbeli stabilitás tünik ki. Az eredmények további elemzésével azonban legalább két érdekes megállapítást tehetünk. Feltủnó egyrészt a diplomások többiektől való határozottabb térbeli elkülönülése - a teljes övezetet figyelve a legmagasabb szegregációs értékeket a két szélső, azaz az iskolázatlan-diplomás csoportok összehasonlításánál láthatjuk, ezt követi a diplomás-diploma nélküli, majd az iskolázatlan-iskolázott csoportok összevetése. Az eredményekből úgy tủnik, a magasabb diplomás aránynyal rendelkező települések jobban elkülönülnek, mint az alacsonyabb iskolázottsággal jellemezhető területek. Jól látszik másrészt a városok és falvak közötti különbség is. Míg a városok esetében nem történt érdemi elmozdulás, addig a falvak tekintetében szignifikáns a változás a bemutatott három időpont között. Az agglomerációs övezet városaiban, a teljes területhez hasonlóan, az időbeli stabilitás a jellemzö, a vizsgált csoportok közötti szegregáltság foka pedig valamivel a teljes területen tapasztaltak alatt marad. Érdekesebb képet mutat ezeknél a községek táblázata. Mind a Disszimilaritás, mind a Gini index azt mutatja, hogy 1980 és 2001 között erősödött a falvak közötti széthúzás - egyre jobban elkülönülnek a lakosságszámukhoz viszonyítva több diplomással büszkélkedő falvak. Míg az iskolázatlanok és iskolázottak között mért szegregáció itt sem mutat érdemi változást, addig a diplomások és diploma nélküliek, valamint a diplomások és iskolázatlanok térbeli egyenlőtlensége jelentősen erősödött a két évtized alatt. Az agglomeráció falvai között tehát jelentősebb a legmagasabb befejezett iskolai végzettség alapján történő elkülönülés mértéke és számottevőbb annak erősödése is, mint ugyanez az agglomeráció városai, vagy a teljes településgyürủ esetében. Úgy tünik, hogy bizonyos 
falvakban magasabb és jobban nö a diplomások aránya, mint máshol, ami egyes községek egyre inkább városias jellegét adhatja. Mint később látható lesz, ezek a községek nagyrészt az agglomerációs gyürü nyugati, északnyugati területein fekszenek. Az agglomeráció más községeiben - leginkább a déli, délkeleti községekben - az elöbbiekkel szemben a lakók iskolázottsági szintje nem változik az átlagosnál nagyobb mértékben, ezek a települések így feltehetően inkább megtartják eredeti jellegüket is.

Összességében tehát a magasabb diplomás arányú területek egyre erősebb szegregálódását láthatjuk, amely jelenséget, ha térben megvizsgálunk, még pontosabb képet kaphatunk. Az elöbbiekben felvázolt szegregációs jelenségek konkrét térbeli megnyilvánulása a térképi ábrázolás, illetve egyéb adatok alapján és újabb módszerek alkalmazásával mutatható be. A szegregációs indexek a térbeli elkülönülés mértékét képesek bemutatni, a területek közötti elkülönülés mintázatát és a lehetséges időbeli átrendeződéseket csak további elemzések során deríthetjük ki. Ha térképen ábrázoljuk az agglomerációs övezet településein élök iskolai végzettségét, pontosabb képet kaphatunk a szegregáció térbeli megnyilvánulásáról.

Az ábrák jól szemléltetik a magas diplomás aránnyal rendelkező települések egyre nagyobb térbeli közeledését, illetve azt, hogy a teljes terület északnyugati és délkeleti szektora egyre jobban távolodik egymástól. Ha az egyes településeken megfigyeljük a diplomások (1.ábra), vagy éppen az iskolázatlanok népességen belüli arảnyát és ennek időbeli változását, akkor az agglomerációs gyürủ térképén kirajzolódik egy szektoriális és egy kör-körös elrendeződés is. Ez a területi struktúra már az elemzés első időpontjában, 1980-ban is egyértelműen létezett, azóta azonban határozottan erősödött, tovább kristályosodott. Egyértelmü, hogy ebben a tekintetben az agglomerációs gyủrủ nyugati, északnyugati területei vannak a legjobb (és egyre javuló) helyzetben, ezt követik a keleti (igencsak heterogén) részek, majd a sort jelentősen leszakadva a déli, délkeleti (leszakadó) terület zárja. Mindemellett megfigyelhetö a fövárostól távolabb fekvő településekhez képest az ahhoz közelebbiek magasabb státusza, jobb helyzete is.

A területen, különösen a falvak között és különösen a diplomások körében látott szegregáció magas szintje és növekedése mögött különböző társadalmi folyamatok húzódhatnak meg. Feltételezhetö, hogy nagymértékben hozzájárul ehhez a Budapestről kiköltözők eltérő iskolai végzettségi szintje, illetve a kiköltözések irányának iskolai végzettség szerinti különbözősége, amely feltételezés egybecseng a Budapestről induló, sugárszerü kiköltözések elméletével is. Valószínüsíthető, hogy a budai oldalon fekvô agglomerációs települések kedvezöbb fekvésüknél, helyzetüknél, könnyebb megközelíthetőségüknél, előnyösebb földrajzi adottságaiknál fogva erősebb vonzóeröt jelentenek a magasabban képzett költözni szándékozók körében, a másik oldalon pedig elérhetetlenek az alacsonyabban iskolázottak számára. Ezek a területek tekinthetök tehát Budapest igazi szuburb területeinek. A másik oldalon, a déli területeken úgy tủnik, nem a klasszikus szuburbanizáció okozza az ott is megfigyelhető népességnövekedést. Minthogy az itt fekvő településeken a diplomások aránya, azaz a magasan kvalifikáltak aránya nem vagy csak jóval kisebb mértékben nö, úgy tünik, ez a 
társadalmi réteg nem, illetve kevésbé szerepel a beköltözők között. A déli szektor vándorlási különbözetének 1990 és 2001 közötti pozitív egyenlegéből arra lehet következtetni, hogy az e területet választók iskolázottsági szintje, ezzel pedig társadalmi státusza alacsonyabb, ha nem is a legalacsonyabb. A szubur-banizáció magyarázatot ad a magas státuszúak magvárosból történő kiköltözésére, az alacsony státuszúakéra azonban nem. Kérdés, hogy milyen okok állhatnak a szegényebb rétegekböl kikerülök költözései mögött. Bizonyos kutatások (Ladányi-Szelényi 1997; Kovács 1999; Csanádi-Csizmady 2002) arra hívják fel a figyelmet, hogy ezek a költözések lényegében kényszer-költözések, amelyeket a fóvárosban való lakhatás ellehetetlenülése magas költsége, nem elégséges munkahely-kínálata - vált ki.

\section{1. ÁBRA}

A diplomások aránya a budapesti agglomerációs övezet egyes településein, \% (településszám) - 1980, 1990., 2001.

(The Proportion of the Degree Ones in the Agglomeration's Settlements)
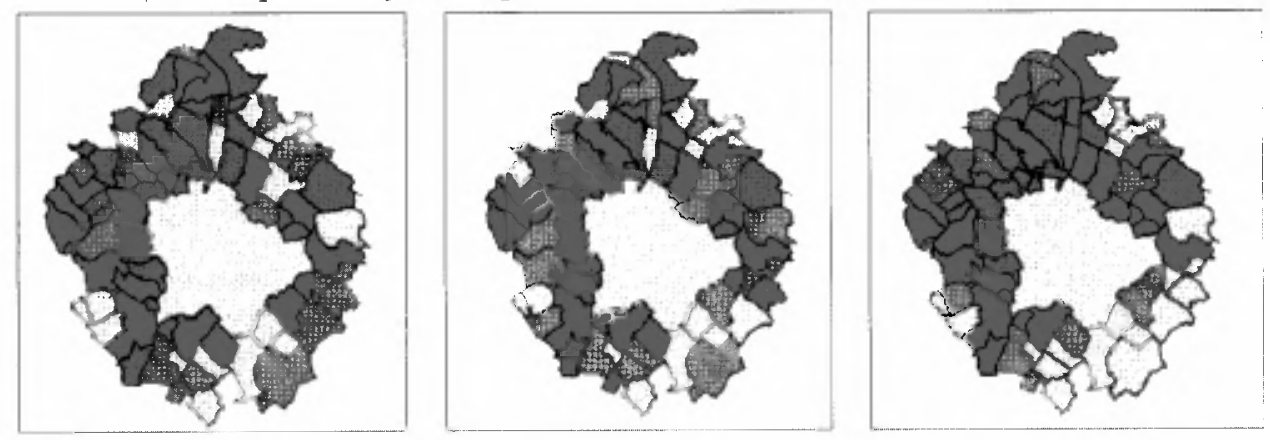

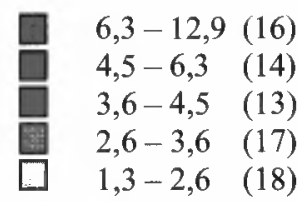

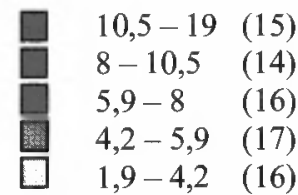

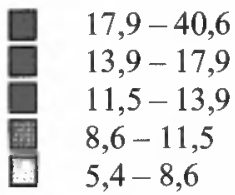

${ }^{x}$ Megjegyzés: Az egyes kategóriákba került települések száma.

Forrás: Saját szerkesztés.

\section{Minóségi mutató: lakáshelyzet}

Az agglomerációs övezet lakáshelyzetének alakulását két dimenzióban vizsgáljuk: az újonnan épült és régebbi, valamint a komfortfokozat szerint elkülönülỏ lakások arányait hasonlítjuk össze a megfelelő párosításokban. Megnézzük a területi szegregációt az új (utóbbi tíz évben épült) és régebbi lakások, illetve az összkomfortos és rosszabb, a komfort nélküli és jobb, valamint az összkomfortos és komfort nélküli lakások tekintetében is. Természetesen itt is meg kell jegyezni, hogy az agglomeráció valamennyi területén a vizsgált időszakban összességében emelkedett az összkomfortos és csökkent a komfort nélküli lakások aránya. 


\begin{tabular}{|c|c|c|c|}
\hline \multicolumn{4}{|c|}{$\begin{array}{l}\text { 4. TÁBLÁZAT } \\
\text { Lakásépitési év szerinti szegregáció az a }\end{array}$} \\
\hline & 1980 & 1990 & 2001 \\
\hline & \multicolumn{3}{|c|}{ Utóbbi 10 évben-korábban } \\
\hline Disszimilaritás index & 0,158 & 0,141 & 0,156 \\
\hline Gini index & 0,219 & 0,192 & 0,224 \\
\hline
\end{tabular}

Forrás: Saját számítás.

\section{TÁBLÁZAT}

Lakásépitési év szerinti szegregáció az agglomerációs övezet városaiban és falvaiban (Building Segregation in the Agglomeration's Cities and Villages)

\begin{tabular}{|c|c|c|c|c|c|c|}
\hline & \multicolumn{3}{|c|}{ Városok } & \multicolumn{3}{|c|}{ Falvak } \\
\hline & 1980 & 1990 & 2001 & 1980 & 1990 & 2001 \\
\hline & \multicolumn{3}{|c|}{$\begin{array}{l}\text { Utóbbi } 10 \text { évben- } \\
\text { korábban }\end{array}$} & \multicolumn{3}{|c|}{$\begin{array}{c}\text { Utóbbi } 10 \text { évben- } \\
\text { korábban }\end{array}$} \\
\hline $\begin{array}{l}\text { Disszimilaritás } \\
\text { index }\end{array}$ & 0,149 & 0,123 & 0,142 & 0,148 & 0,152 & 0,170 \\
\hline Gini index & 0,197 & 0,165 & 0,196 & 0,210 & 0,207 & 0,239 \\
\hline
\end{tabular}

Forrás: Saját számítás.

A lakáshelyzet alakulását elemezve, talán kevésbé látványos, de az elöbbiekhez hasonló eredményeket kapunk. A vizsgált időpontok között közepes szintü a szegregáció, ami a falvak között mutat kisebb, de szignifikáns elmozdulást, mind a komfortfokozatot (7. táblázat), mind a lakásépitéseket (5. táblázat) tekintve. A komfortfokozat szerinti szegregáció esetében (6., 7. táblázat) kicsit bonyolultabb képet kapunk. Miközben az agglomeráció városai között az összkomfortos lakások szegregáltsága közepes, a falvak esetében ugyanez alacsony értékről nagymértékü növekedéssel a városokéhoz hasonló közepes értékre ugrik. A községek körében tehát erőteljesen nő az ősszkomfortos lakások szegregáltsága. A két szélsỏ csoportot, azaz a komfort nélküli és rosszabb, valamint az összkomfortos lakások térbeli elhelyezkedését összehasonlítva a teljes agglomerációs gyürüben közepes, csökkenő tendenciát mutató szegregáció látszik a két csoport között. Hasonló a változás az agglomerációs városok esetében is, míg a községek helyzete ezekkel ellentétesen alakul. 1990 és 2001 között nem kismértékü csökkenés, hanem ugyancsak kismértékü, de növekedés figyelhető meg a szegregációs indexek értékei között. Ezt a növekedést feltehetően nem a rosszabb lakások, hanem a jobb lakások szegregációjának növekedése okozza. Az agglomerációs gyürün belül itt is a falvak produkálták tehát a nagyobb változást, és ebben az esetben is inkább a felsőbb rétegek erőteljesebb elkülönülésére lehet következtetni. Feltehetö, hogy ezeknek az eredményeknek a kialakulásához nagymértékben hozzájárult a (magas igényeket kielégíteni szándékozó, ezzel a magasabban kvalifikált beköltözni vágyókat megcélzó) lakóparkok elszaporodása, mely folyamat a vizsgált időintervallum óta még tovább erősödött. 


\section{TÁBLÁZAT}

Komfortfokozat szerinti szegregáció az agglomerációs övezetben ${ }^{13}$

(Comfort Level Segregation in the Agglomeration)

\begin{tabular}{lcc}
\hline & 1990 & 2001 \\
\hline & \multicolumn{1}{c}{ Össkomfortos - rosszabb } \\
Disszimilaritás index & 0,154 & 0,182 \\
Gini index & 0,219 & 0,248 \\
\hline & \multicolumn{1}{c}{ Komfort nélküli - jobb } \\
Disszimilaritás index & 0,198 & 0,180 \\
Gini index & 0,283 & 0,256 \\
\hline & Komfort nélküli - összkomfortos \\
Disszimilaritás index & 0,229 & 0,200 \\
Gini index & 0,315 & 0,282 \\
\hline
\end{tabular}

Forrás: Saját számítás.

\section{TÁBLÁZAT}

Komfortfokozat szerinti szegregáció az agglomerációs övezet városaiban és falvaiban (Comfort Level Segregation in the Agglomeration's Cities and Villages)

\begin{tabular}{|c|c|c|c|c|}
\hline & \multicolumn{2}{|c|}{ Városok } & \multicolumn{2}{|c|}{ Falvak } \\
\hline & 1990 & 2001 & 1990 & 2001 \\
\hline & \multicolumn{2}{|c|}{ Összkomfortos - rosszabb } & \multicolumn{2}{|c|}{ Összkomfortos - rosszabb } \\
\hline $\begin{array}{l}\text { Disszimilaritás } \\
\text { index }\end{array}$ & 0,165 & 0,186 & 0,119 & 0,164 \\
\hline \multirow[t]{2}{*}{ Gini index } & 0,233 & 0,252 & 0,167 & 0,223 \\
\hline & \multicolumn{2}{|c|}{ Komfort nélküli-jobb } & \multicolumn{2}{|c|}{ Komfort nélküli-jobb } \\
\hline $\begin{array}{l}\text { Disszimilaritás } \\
\text { index }\end{array}$ & 0,199 & 0,181 & 0,155 & 0,164 \\
\hline \multirow[t]{2}{*}{ Gini index } & 0,266 & 0,225 & 0,212 & 0,220 \\
\hline & \multicolumn{2}{|c|}{$\begin{array}{l}\text { Komfort nélküli - össz- } \\
\text { komfortos }\end{array}$} & \multicolumn{2}{|c|}{$\begin{array}{l}\text { Komfort nélküli - össz- } \\
\text { komfortos }\end{array}$} \\
\hline $\begin{array}{l}\text { Disszimilaritás } \\
\text { index }\end{array}$ & 0,218 & 0,181 & 0,168 & 0,195 \\
\hline Gini index & 0,297 & 0,237 & 0,236 & 0,258 \\
\hline
\end{tabular}

Forrás: Saját számítás.

Ha a szegregációs indexekkel történő elemzést most is kiegészítjük az egyes településeken újonnan vagy régebben épült lakások, illetve az összkomfortos vagy a komfort nélküli lakások arányának és ezek időbeli változásának térképi ábrázolásával és annak vizsgálatával, ismét megfigyelhetjük a szegregáció valódi térbeli megjelenését, mintázatát. E térképek segítségével (2. ábra) látható, hogy amíg az 1980 elötti évtizedben még elszórtan, addig 1990 és 2001 között már két gócra fókuszálva épül- 
tek elsősorban új lakások: északkeleten és északnyugaton (nem meglepő módon az autópályák mentén). Nem véletlen az sem, hogy az itt található települések egyben az övezet legdinamikusabban fejlödö, lakosságszámukban leggyorsabban növekvő települései közé tartoznak. Bemutatható továbbá, hogy 1990 és 2001 között a községekben meghaladta a lakásépítések száma a városokét, ami feitehetỏen egyrészt e települések tudatos lakosságszám növelési stratégiảinak, másrészt az ezt megvalósítani szándékozó egyre népszerübb lakópark-építéseknek köszönhetö. Ez az eredmény is egybecseng a vándorlási mutatószámokkal. Bár természetes, hogy nemcsak építkezéssel lehet az agglomerációban letelepedni, illetve, hogy az újépítésü lakásokba nem csak az újonnan és nem csak a Budapeströl érkezök költözhetnek be, a szakirodalom mégis ezt valószínủsíti. A lakáshelyzetet vizsgálva is megfigyelhető a szektoriális és a körkörös elrendeződés. Az iskolai végzettség elemzésénél tapasztaltakhoz hasonlóan itt is azt láthatjuk, hogy a nyugati területek vannak a legjobb helyzetben, ezeket követi a keleti, igen heterogén régió, majd a déli, az elöbbiektől jelentősen lemaradó övezet.

Úgy tűnik tehát, hogy a budapesti agglomerációs gyürủ a vizsgált dimenziók alapján közepes, enyhén fokozódó szegregáltságú. A régióban három nagyobb, összefüggő terület rajzolódik ki, amelyek társadalmi összetétele alapvetően eltér egymástól. Ezek az agglomerációs gyürü nyugati, déli és északkeleti területei. A nyugati, különösen az északnyugati területek a klasszikus közép- és felsöosztályi szuburbanizáció célterületei. Jellemző a területre az egyre magasabb általános társadalmi státusz és ezzel párhuzamosan a növekvő fejlettség. Feltehető, hogy az odaköltözők többnyire a magasabb társadalmi rétegekből érkeznek, és ezzel folyamatosan emelik a terület státuszát. A déli szektorra inkább a szegénységi „,szuburbanizáció” jellemző, ami az alacsonyabb státuszúak feltehetően kényszer-jellegü költözéseiböl alakul ki. Ezek a területek már a kiköltözési folyamat megindulása elött is a rosszabb gazdasági, társadalmi helyzetü területekhez tartoztak, így egy hasonló összetételủ lakosság megjelenésével helyzetüket stabilizálhatják, ezzel pedig tovább erösíthetik leszakadásukat. A keleti, északkeleti szektor a legheterogénebb terület az agglomerációban. Az agglomeráció szerkezete tehát nem egységes: egyaránt áll dinamikusan fejlődö szuburbán, és leszakadó, hátrányosabb helyzetü összefüggő területekböl.

A szektoros felosztás mellett egy másik, szintén említésre méltó, de nem meglepő területi elkülönülés is kirajzolódik. Ez a teljes övezetben a körkörös, azaz az egyes szektorokon belül a réteges területi elhelyezkedés. Nem meglepő, hogy a Budapesttel határos települések nagyobb része tartozik a magasabb státuszúak közé, mint az attól távolabbi területek városai vagy falvai. 


\section{2. ÁBRA}

Az utóbbi tíz évben épült lakások aránya az összes lakáshoz viszonyitva a budapesti agglomerációs övezet egyes településein, \% (településszám) - 1980, 1990., 2001. (The Proportion of New Flats in the Agglomeration's Settlements)
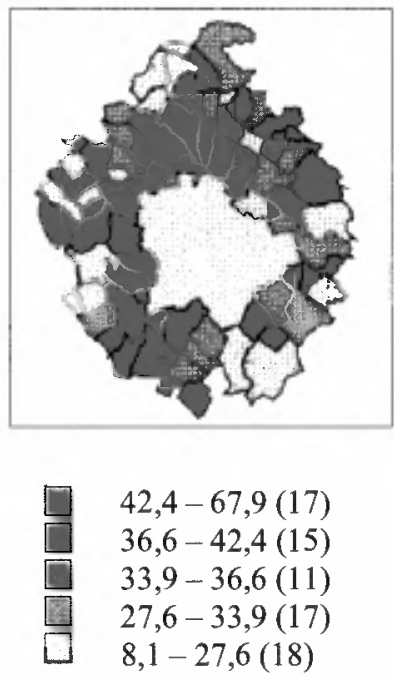
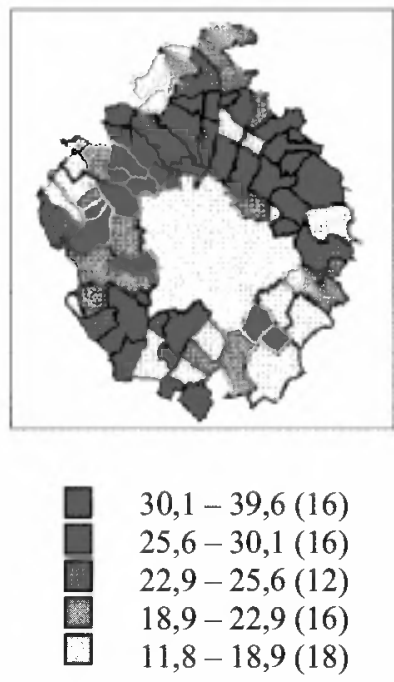
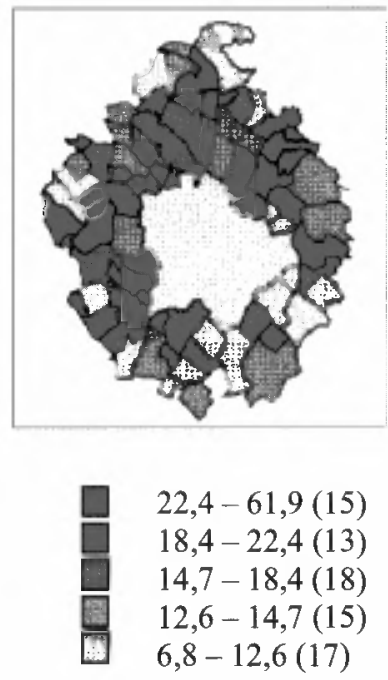

${ }^{x}$ Megjegyzés: Az egyes kategóriákba került települések száma.

Forrás: Saját szerkesztés.

Mindkét bemutatott dimenzió rávilágít továbbá az agglomerációs övezet településtípusainak eltérỏ szerkezet-változására is. Míg a városok esetében az időbeli változás lassú, egymáshoz képest a városok nem távolodnak jelentős mértékben, addig a falvak jóval erőteljesebb elkülönülést, széthúzást mutatnak. Ennek oka minden bizonnyal az, hogy a városok többsége városi mivoltuknak köszönhetően eleve jobb helyzetben volt, szerkezetük, lakosság-összetételük egymáshoz jobban hasonlított városias volt. Ezzel szemben az agglomeráció falvai közül, leginkább a nyugati területeken fekvők, falusi helyzetükből az utóbbi évtizedben közel városi helyzetet tudtak teremteni - népességnövekedésükkel (és az új lakosok igényeinek többékevésbé sikeres kiszolgálásával) rohamosan megindultak az urbanizálódás útján. Ez a jelenség egyúttal a város-falu közti különbség elmosódását, és a falvak közötti erősödó széthúzást is magában hordozza.

\section{Összegzés}

Minden jel arra utal, hogy ma Budapest agglomerációs övezete komoly társadalmi átrendeződési folyamatok színhelye. A jelentős mértékủ lakosságcsere, a nagyarányú ki- és beköltözések olyan mintázatok szerint történnek, amelyek az agglomerációs gyürủ struktúráját tovább erősítik. Mind a települések között, mind az egyes településeken belül egyre erősödik a térbeli társadalmi elkülönülés, a szegregáció, amelynek 
(legalábbis egyik fontos) oka az új lakosok célirányos beköltözése, tudatos lakóhely választása - a magasabb gazdasági, társadalmi csoportokból érkezök gyakori elkülönülési igénye, az alacsonyabb rétegekböl érkezők kényszerủ elszeparálódása. Érdekes jelenség, hogy szembetünőbb a magasabb státuszú lakók és települések térbeli tömörülése, mint a szegényebb rétegeké. Míg az elöbbiek térben közel, kisebb tömbökben, addig az utóbbiak, úgy tünik, térben elszórtabban, nagyobb területen koncentrálódnak.

\section{Jegyzetek}

I Jelen tanulmány alapját a „Szegregáció Budapest agglomerációs övezetében” címü (az ELTE Szociológia szakára írott) szakdolgozatom képezi. Az akkor végzett elemzést, az azóta eltelt időben folytattam, így jelen tanulmány is az agglomerációs problémákkal foglalkozó (a Corvinus Egyetem PhD képzésének keretein belül készülő) doktori disszertációm része.

${ }^{2} \mathrm{Az}$ eröltetett gazdaságfejlesztés nagy tömegeket vonzott a fóvárosba, a lakásépítés vagy az infrastruktúra fejlesztése azonban nem tudta követni a növekvő igényeket, ezért központilag korlátozták a föváros területén való letelepedést.

${ }^{3}$ A területfejlesztésröl és területrendezésröl szóló 1996. évi XXI. törvény felhatalmazása alapján, a 89/1997. (V.28.) számú kormányrendelet.

${ }^{4}$ 2002. október 20-án Nagykovácsi község területrészéből Remeteszölős néven, valamint Sződ község területrészéböl Csörög néven új községek alakultak.

${ }^{5}$ A legnagyobb agglomerációt, összesen 160 települést Iván László feltételez. A jelenlegi településeken kivül Pest, Fejér és Komárom-Esztergom megyék azon településeit is az agglomerációhoz sorolja, amelyek kutatásai szerint a fơváros tágabb munkaerö-vonzási körzetébe tartoznak. Valér Éva 123 települést sorol az agglomerációba, köztük Fejér, Nógrád és Komárom-Esztergom megyékbe tartozó területeket is. Kőszegfalvi György kutatásai során csupán 72 település területével számol, amelyek között nem szerepel mindegyik, a hivatalos lehatároláson belül található település. Tóth Judit 92 település besorolását tartja indokoltnak, míg Beluszky Pál közel 160 települést sorol ide (Sági-Trócsányi 1998). Az agglomerációs övezetbe tartozó települések szektoronként:

Északnyugati szektor: Budakalász, Csobánka, Dunabogdảny, Kisoroszi, Leányfalu, Nagykovácsi, Pilisborosjenő, Piliscsaba, Pilisjászfalu, Pilisszántó, Pilisszentiván, Pilisszentkereszt, Pilisszentlászló, Pilisvörösvár, Pócsmegyer, Pomáz, Solymár, Szentendre, Szigetmonostor, Tahitótfalu, Üröm, Visegrád + Remeteszőlös.

Nyugati szektor: Biatorbágy, Budajenő, Budakeszi, Budaörs, Herceghalom, Páty, Perbál, Telki, Tinnye, Tök, Törökbálint, Zsámbék.

Déli szektor: Délegyháza, Diósd, Dunaharaszti, Dunavarsány, Érd, Halásztelek, Majosháza, Pusztazámor, Sóskút, Százhalombatta, Szigethalom, Szigetszentmiklós, Taksony, Tárnok, Tököl.

Délkeleti szektor: Alsónémedi, Ecser, Felsőpakony, Gyál, Gyömrő, Maglód, Ócsa, Üllő, Vecsés.

Keleti szektor: Csömör, Erdőkertes, Gödöllö, Isaszeg, Kerepes, Kistarcsa, Mogyoród, Nagytarcsa, Pécel, Szada, Veresegyház.

Északi szektor: Csomád, Dunakeszi, Fót, Göd, Őrbottyán, Sződ, Sződliget, Vác, Vácrátót + Csörög.

${ }^{7}$ Ezeken kívül a fontosabb indexek még: az Entrópia index, az Atkinson index, az Interakciós index, az Izolációs index, a Korrelációs index és a Delta index.

${ }^{8}$ A mutatókban szereplö jelölések jelentései:

$\mathrm{n}$ a vizsgált területi egységek száma $(\mathrm{db})$

T a teljes terület népessége (fö)

$\mathrm{P}$ a teljes terület kisebbségi aránya $t_{\mathrm{i}}$ az i-edik körzet teljes népessége (fö)

$\mathrm{t}_{\mathrm{j}}$ a j-edik körzet teljes népessége (fö)

$\mathrm{p}_{\mathrm{i}}$ az i-edik körzet kisebbségi aránya

$\mathrm{p}_{\mathrm{j}}$ a j-edik körzet kisebbségi aránya 
${ }^{9}$ Disszimilaritás index:

$$
\underline{\sum_{i=1}^{n}\left[t_{i}\left|p_{i}-P\right|\right]}
$$

$$
[2 \mathrm{TP}(1-\mathrm{P})]
$$

${ }^{10}$ Gini index:

$$
\frac{\sum_{i=1}^{n} \sum_{j=1}^{n} t_{i} t_{j}\left|p_{i}-p_{j}\right|}{2 T^{2} P(1-P)}
$$

${ }^{11}$ Míg az Egyesült Államokban a szegregált területek disszimilaritás értékei 60-80\% között mozognak, addig Magyarországon a 20-30\%-os értékek már jelentős térbeli elkülönülésre utalnak.

12 Habár a következő népszámlálás adatai még nem állnak rendelkezésre, elképzelhető, hogy azokból már egyfajta visszaköltözési tendencia is kimutatható lesz.

${ }^{13}$ Habár a komfortfokozatot az 1980-as népszámlálás alkalmával is kérdezték, a településsoros adatok hiányoznak az évkönyvekböl.

\section{Irodalom}

Beluszky P. (1999) A budapesti agglomeráció kialakulása. - Barta Gy.-Beluszky P. (szerk.) Társadalmigazdasági átalakulás a budapesti agglomerációban. Regionális Kutatási Alapítvány, Budapest. 27-68. o.

Beveridge, A. (2002) Segregation. The Measurement of Inequality, Queens College, New York. http://www.gothamgazette.com/demographics/mar.02.shtml

Csanádi G.-Csizmady A. (2002) Szuburbanizáció és társadalom. - Tér és Társadalom. 3. 27-55. o.

Kovács K. (1999) A szuburbanizációs folyamatok a fövárosban és az agglomerációban. - Barta Gy.Beluszky P. (szerk.) Társadalmi-gazdasági átalakulás a budapesti agglomerációban. Regionális Kutatási Alapítvány, Budapest. 91-114. o.

KSH (1980) Az 1980. évi népszámlálás területi adatai. Pest megye. Központi Statisztikai Hivatal, Budapest. KSH (1990) Az 1990. évi népszámlálás területi adatai. Pest megye. Központi Statisztikai Hivatal, Budapest.

KSH (1998) Közlemények a budapesti agglomerációról. 8. A budapesti agglomeráció az ezredforduló küszöbén. Központi Statisztikai Hivatal, Budapest.

KSH (2001) A 2001. évi népszámlálás területi adatai. Pest megve. Központi Statisztikai Hivatal, Budapest. Ladányi J.-Szelényi I. (1997) Szuburbanizáció és gettósodás - Kritika. 7. 4-12. o.

Massey, D.S.-Denton, N.A. (1988) The Dimensions of Residential Segregation. - Social Forces. 2. 281-315. o.

Sági Zs.-Trócsányi A. (1998) Szegregáció a budapesti agglomerációs övezetben. - Földrajzi Értesitö. 2. füzet. 235-248. o.

Schuchmann P. (2001) Városi terjeszkedés a budapesti agglomerációban. - Éri V. (szerk.) Terjeszkedés vagy ésszerü városfejlödés. Környezettudományi Központ, Budapest.

Szirmai V. (1998) A budapesti agglomeráció társadalmi problémái. - Társadalmi Szemle 7. 18-28. o. 